\title{
PENGARUH LAYANAN PENGUASAAN KONTEN DENGAN TEKNIK MODELING UNTUK MENGURANGI KECEMASAN BERBICARA SISWA DI DEPAN KELAS DI SMP N 13 KOTA BENGKULU
}

\author{
Andika Safutra, Syahriman, Vira Afriyati \\ Prodi Bimbingan dan Konseling Fakultas Keguruan dan Ilmu Pendidikan \\ Universitas Bengkulu \\ andikasafutra93@yahoo.com,syahriman@unib.ac.id,viraafriyati@unib.ac.id
}

\begin{abstract}
ABSTRAK
Penelitian ini bertujuan untuk mendeskripsikan pengaruh layanan penguasaan konten dengan teknik modeling untuk mengurangi kecemasan berbicara siswa di depan kelas di SMP N 13 Kota Bengulu. Penelitian ini merupakan penelitian eksperimen dengan desain penelitian one grup pretest dan postest. Teknik sampling yang digunakan adalah purposive sampling dimana sampel pada penelitian ini adalah siswa kelas VIII A SMP N 13 Kota Bengkulu. Hasil yang diperoleh dalam penelitian ini menunjukkan adanya penurunan signifikan pengaruh layanan penguasaan konten dengan teknikmodelinguntuk mengurangi kecemasan berbicara siswa di depan kelas. Hal ini dapat terlihat dari hasil pengujian hipotesis dengan hasil nilai uji t 17.054, nilai sig sebesar 0,000 (< 0,005) maka $\mathrm{H}_{0}$ ditolak. Dapat disimpulkan, terdapat pengaruh layanan penguasaan konten dengan teknik modeling untuk mengurangi kecemasan berbicara siswa di depan kelas.
\end{abstract}

Kata kunci: Layanan Penguasaan Konten, Teknik Modeling, Kecemasan berbicara

\section{THE INFLUENCE OF CONTENT SERVICE USING MODELING TECHNIQUES TO REDUCE THE ANXIETY WHEN SPEAKING IN FRONT OF THE CLASS AT SMP N 13 BENGKULU}

\begin{abstract}
This study aims to describe the effect of content mastery services with modeling techniques to reduce the anxiety of speaking students in front of the class in Bengulu City 13 Middle School.This research is an experimental study with one group pretest and posttest research design.The sampling technique used was purposive sampling where the sample in this study were students of class VIII A SMP N 13 Kota Bengkulu. The results obtained in this study indicate a significant reduction in the influence of content mastery services with modeling techniques to reduce the anxiety of speaking students in front of the class. This can be seen from the results of testing hypotheses with the results of the t test value of 17,054 , the sig value of $0,000(<0,005)$ then $\mathrm{H}_{0}$ is rejected.It can be concluded, there is an effect of content mastery services with modeling techniques to reduce anxiety speaking students in front of the class.
\end{abstract}

Keywords: Content Mastery Service, Modeling Technique, Speech Anxiety 


\section{Pendahuluan}

Pendidikan adalah salah satu wadah seseorang untuk mencapai cita-cita yang diinginkan. Dunia pendidikan juga sebagai wadah untuk mengembangkan potensi seseorang termasuk kemampuan berbicara. Seperti yang diketahui bahwa di dalam dunia pendidikan kemampuan berbicara adalah penunjang kelancaran proses belajar mengajar. Kemampuan berbicara adalah salah satu bagian dalam dunia pendidikan untuk membantu interaksi dan berkomunikasi satu sama lain serta sangat dibutuhkan untuk setiap jenjang pendidikan.

Pendidikan merupakan salah satu hal yang sangat penting untuk anak-anak Indonesia, seperti yang tertera dalam Pasal 1 Ayat (1) UU No. 20/2003 tentang sistem Pendidikan Nasional menyatakan bahwa:

Pendidikan adalah usaha sadar dan terencana untuk mewujudkan suasana belajar dan proses pembelajaran agar peserta didik secara aktif mengembangkan potensi dirinya untuk memiliki kekuatan sprititual keagamaan, pegendalian diri, kepribadian, kecerdasan, akhlak mulia serta keterampilan yang diperlukan dirinya, masyarakat, bangsa dan negara. (Prayitno 2004).

Setiap orang dapat berbicara namun tidak setiap orang dapat berbicara dengan baik dan komunikatif di depan umum. Berbicara adalah cara seseorang berkomunikasi dengan orang lain untuk menyampaikan sesuatu yang diinginkan. Komunikasi menentukan kualitas kehidupan manusiadan memiliki kemampuan berkomunikasi yang efektif sangatlah diperlukan untuk menyampaikan ide, gagasan, dan pengetahuan kepada masyarakat. Menurut Hafied Cangara, (2011: 4) komunikasi adalah salah satu aktivitas yang sangat fundamental dalam kehidupan umat manusia. Kebutuhan manusia untuk berhubungan dengan sesamanya, diakui oleh hampir semua agama telah ada sejak Adam dan Hawa.

Salah satu masalah yang dihadapi dikalangan siswa di sekolah yang berkaitan dengan komunikasi adalahkecemasan berbicara. Kecemasan berbicara adalah suatu bentuk perasaan takut dan mengalami gerogi yang dialami setiap siswa. Karena rasa cemas hampir tejadi pada setiap diri manusia. Menurut Prakoso dan Partini (2015: 40) perasaan cemas atau gerogi saat mulai berbicara di depan umum adalah hal yang seringkali dialami kebanyakan orang bahkan 
seseorang yang telah berpengalaman berbicara di depan umum pun tidak terlepas dari perasaan ini.

Sehubungan masalah yang dihadapi oleh siswa-siswi di sekolah maka peneliti ingin menggunakan Layanan Penguasaan Konten dengan Teknik Modeling karena menurut peneliti Layanan Penguasaan Konten dengan Teknik Modeling ( Penokohan) sangat efektif bila diberikan kepada peserta didik untuk mengurangi kecemasan berbicara. Menurut Prayitno (2004: 2) Layanan Penguasaan Konten (PKO) merupakan layanan bantuan kepada individu (sendirisendiri ataupun dalam kelompok) untuk menguasai kemampuan atau kompetensi tertentu melalui kegiatan belajar. Layanan penguasaan konten membantu individu menguasai aspek-aspek tersebut secara tersinergikan. Tujuan utama layanan penguasaan konten ialah dikuasainya suatu konten tertentu, penguasaan ini perlu bagi siswa untuk menambah wawasan dan pemahaman, mengarahkan penilaian dan sikap, menguasai cara-cara atau kebiasaan tertentu, untuk memenuhi kebutuhannya dan mengatasi masalah-masalahnya.

Menurut Albert Bandura (dalam Damayanti dan Aeni 2016: 100) dengan teori belajar sosial, terdapat pula teori behavior modeling yang berakar dari teori belajar sosial yang dimulai pada tahun 50-an. Teori Behavior Modeling merupakan belajar melalui observasi dengan menambahkan atau menurangi tingkah laku yang teramati, menggeneralisir berbagai pengamatan sekaligus melibatkan proses kognitif. Sejalan dengan pengertian dan tujuan dari layanan penguasaan konten dengan teknik modeling, dapat disimpulkan bahwa layanan penguasaan konten dengan teknik modeling sangat cocok untuk mengatasi kecemasan berbicara siswa khusunya bagi siswa yang mengalami kecemasan berbicara di depan kelas maupun di muka umum, agar siswa dapat menambah kepercayaan diri serta dapat meningkatkan kemapuan berbicara mereka.

Dari pengalaman yang diperoleh dari berbagai kegiatan mulai dari magang serta studi kasus, peneliti pun melakukan kegiatan observasi dan wawancara lanjutan di sekolah SMPN 13 Kota Bengkulu, di sekolah tersebut peneliti menemui Guru Bimbingan dan Konseling, memang menuturkan bahwa dikalangan siswa SMPN 13 Kota Bengkulu masih banyak yang megalami 
kecemasan berbicara di depan kelas maupun di muka umum saat di suruh maupun atas keinginan sendiri. Menurut fakta dilapangan masih ada siswa yang mengalami kurang percaya diri, takut salah, gugup, cemas, serta perilaku menghindar apabila disuruh oleh guru berbicara didepan kelas. Mereka mengalami kecemasan berbicara yang membuat komunikasi mereka kurang efektif.

Berdasarkan uraian di atas, maka munculah ketertarikan penulis untuk melakukan penelitian dengan judul "Pengaruh Layanan Penguasaan Konten dengan Teknik Modeling Untuk Mengurangi Kecemasan Berbicara Siswa di Depan Kelas".

\section{Metode Penelitian}

Metode yang digunakan dalam penelitian ini adalah penelitian eksperimen dengan cara memberikan layanan penguasaan konten dengan tehnik modeling kepada kelompok eksperimen. Proses penelitian yang dilakukan dalam penelitian ini adalah pre eksperimental design dengan jenis desain one group pre-test and post-test design karena tidak ada perbandingan dengan kelompok kontrol, sehingga satu kelompok tes diberikan satu pelakuan yang sama sebelum dan sesudah mendapatkan perlakuan tertentu (Emzir 2015: 96).

Penelitian ini melakukan dua kali pengukuran, pengukuran pertama dilakukan sebelum memberikan layanan penguasaan konten dengan tehnik modeling dan pengukuran yang kedua dilakukan setelah diberikan layanan penguasan konten dengan tehnik modeling.Pola desain penelitian eksperimen dapat digambarkan sebagai berikut :

\section{Gambar 1}

\section{Desain Penelitian}

Pengukuran

(Pre-test)

T1
Pengukuran

(Pos-test) 
Keterangan:

T1 :pengukuran pertama, kecemasan berbicara siswa sebelum diberi perlakuan yang diukur dengan menggunakan angket kecemasan berbicara.

X :memberikan perlakuan layanan penguasaan konten dengan tehnik modeling terhadap siswa SMPN 13 Kota Bengkulu.

T2 :pengukuran kedua, kecemasan berbicara sesudah diberikan treatment berupa layanan penguasaan konten dengan teknik modeling menggunakan instrumen yang sama dengan pengkuran pertama.

Populasi dalam penelitian ini adalah siswa kelas VIII A SMP Negeri 13 Kota Bengkulu.Sampel yang akan diambil pada penelitian ini adalah siswa yang mengalami kecemasan berbicara di depan kelas, kelas VIII A.Teknik pengambilan subjek penelitian pada penelitian ini adalah purposive sampling. Teknik purposive sampling adalah teknik penentuan sampel dengan pertimbangan tertentu (Sugiyono, 2009: 68).

Teknik pengumpulan data yang digunakan pada penelitian ini yaitu menggunakanobservasi dan angket. Menurut Nurkancana (1990: 35) observasi adalah suatu cara pengumpulan data dengan mengadakan pengamatan langsung terhadap suatu obyek dalam suatu periode tertentu dan mengadakan pencatatan secara sistematis tentang hal-hal yang tertentu yang diamati. Teknik pengumpulan data yang digunakan dalam penelitian ini adalah melalui penyebaran instrumen yang berupa angket kecemasan berbicara. Peneliti melakukan pengumpulan data penelitian dengan cara menggunakan angket kecemasan berbicara dengan skala Likert.

Teknik analisis data yang digunakan pada penelitian ini yaitu rumus uji-t. Uji-t digunakan untuk mencari ada atau tidaknya perbedaan sebelum dan sesudah pemberian layanan penguasaan konten dengan teknik modeling untuk mengurangi kecemasan berbicara siswa di depan kelas. 


\section{Hasil dan Pembahasan}

Untuk menentukan kategori perolehan skor populasi, peneliti terlebih dahulu mencari mean dan standar deviasi, dengan menggunakan software statistical packages for social science (SPSS), yang tersaji dalam Tabel 1.

\section{Tabel 1}

\section{Deskripsi Statistik}

\begin{tabular}{lc}
\hline Jumlah sampel $(\mathrm{N})$ & 34 \\
\hline Skor Minimum & 38 \\
\hline Skor Maximum & 190 \\
\hline Mean & 95 \\
\hline Standar Deviasi $(\boldsymbol{\sigma})$ & 31.66 \\
\hline
\end{tabular}

Kuesioner kecemasan berbicara yang terdiri atas 38 item dengan 5 pilihan jawaban yang bergerak dari 1 sampai 5, sehingga diperoleh rentang minimum adalah $38 \times 1=38$ maximum adalah $38 \times 5=190$, sehingga luas jarak sebarannya adalah 190-38=152. Dengan demikian Mean $1 / 2 .(190)=95$. Setiap satuan deviasi standarnya bernilai $1 / 3 .(95)=31.66$.

Dari data tabel 4.1 dapat diketahui:

Mean : :95

standar deviasi $\quad: 31,66$

Jadi, penentuan skornya sebagai berikut :

Sangat tinggi $\quad: 95+1.5(31,66) \quad=142$

Tinggi $\quad: 95+0.5(31,66) \quad=111$

Sedang $\quad: 95 \quad=95$

Rendah $\quad: 95-0.5(31,66) \quad=79$

Sangat rendah $\quad: 95-1.5(31,66) \quad=47$

Berdasarkan perhitungan di atas, dapat disimpulkan bahwa skor dan kategorinya adalah sebagai berikut : 
Tabel 2

\section{Penentuan Kategori}

\begin{tabular}{cc}
\hline Skor & Kategori \\
\hline$>142$ & Sangat Tinggi \\
\hline $111-141$ & Tinggi \\
\hline $95-110$ & Sedang \\
\hline $79-94$ & Rendah \\
\hline$\leq 78$ & Sangat Rendah \\
\hline
\end{tabular}

Tabel 3

Frekuensi Pre-test

\begin{tabular}{ccc}
\hline Interval & Frekuensi & Kategori \\
\hline$>142$ & 24 & Sangat tinggi \\
\hline $111-141$ & 7 & Tinggi \\
\hline $95-110$ & 3 & Sedang \\
\hline $79-94$ & 0 & Rendah \\
\hline$\leq 78$ & 0 & Sangat rendah \\
\hline Total & 34 &
\end{tabular}

Hasil pengolahan pre-test dapat disimpulkan bahwa siswa yang mengalami kecemasan berbicara dengan kategori sangat tinggi serta dengan ketentuan skor $>142$ berjumlah 24 siswa, kategori tinggi dengan rentang skor 111 - 141 terdapat 7 orang siswa, kategori sedang dengan ketentuan skor 95 - 110 terdapat 3 orang siswa, kategori rendah dengan rentang skor 79 - 94 tidak ada yang mengalami atau nihil untuk kategori ini, kategori sangat rendah dengan rentang skor $\leq 78$ juga tidak ada yang mengalami atau nihil untuk kategori ini.

Berdasarkan hasil tersebut dapat diketahui siswa yang mengalami tingkat kecemasan berbicara di depan kelas dengan kategori sangat tinggi, tinggi, sedang, rendah, dan sangat rendah. Langkah selanjutnya di berikan treatment layanan penguasaan konten dengan teknik modeling agar siswa yang mengalami tingkat kecemasan berbicara sangat tinggi, tinggi, dan sedang mengalami perubahan penurunan tingkat kecemasan berbicara siswa di depan kelas setelah adanya diberikan treatment tersebut. 
Tabel 4

Frekuensi Post-test

\begin{tabular}{ccc}
\hline Interval & Frekuensi & Kategori \\
\hline $95-110$ & 3 & Sedang \\
\hline $79-94$ & 20 & Rendah \\
\hline$\leq 78$ & 11 & Sangat rendah \\
\hline Total & 34 & \\
\hline
\end{tabular}

Dari hasil pengolahan post-test dapat disimpulkan bahwa ada perubahan penurunan kecemasan berbicara siswa di depan kelas sebelum dilaksanakan (pretest) dan setelah dilaksanakan (post-test), serta diberikan treatment layanan penguasaan konten dengan teknik modeling. Dari 34 siswa yang diberikan perlakuan layanan penguasaan konten dengan teknik modeling, mengalami perubahan penurunan tingkat kecemasan berbicara siswa di depan kelas yakni dengan kategori sedang ketentuan skor 95 - 110 berjumlah 3 orang, dengan kategori rendah ketentuan skor 79 - 94 berjumlah 20 orang, serta dengan kategori sangat rendah ketentuan skor $\leq 78$ berjumlah 11 orang.

Tabel 5

Penurunan skor

$\begin{array}{cccc}\text { Skor } & \text { Skor } & \text { Skori } \\ \text { No Responden } \\ \text { pre-test }\end{array}$ Kategori Skorpenurunan

\begin{tabular}{ccccclc}
\hline 1 & AGR & 161 & $\begin{array}{c}\text { Sangat } \\
\text { tinggi }\end{array}$ & 79 & Rendah & 82 \\
\hline 2 & ANO & 154 & $\begin{array}{c}\text { Sangat } \\
\text { tinggi }\end{array}$ & 90 & Rendah & 64 \\
\hline 3 & AIK & 144 & $\begin{array}{c}\text { Sangat } \\
\text { tinggi }\end{array}$ & 92 & Rendah & 52 \\
\hline 4 & AP & 127 & Tinggi & 90 & Rendah & 37 \\
\hline 5 & AR & 156 & $\begin{array}{c}\text { Sangat } \\
\text { tinggi }\end{array}$ & 92 & Rendah & 64 \\
\hline 6 & AL & 106 & Sedang & 91 & Rendah & 15 \\
\hline 7 & DML & 155 & $\begin{array}{c}\text { Sangat } \\
\text { tinggi }\end{array}$ & 85 & Rendah & 70 \\
\hline 8 & EUH & 135 & Tinggi & 83 & Rendah & 52 \\
\hline 9 & ES & 171 & Sangat & 80 & Rendah & 91 \\
\hline
\end{tabular}




\begin{tabular}{|c|c|c|c|c|c|c|}
\hline & & & tinggi & & & \\
\hline 10 & EN & 163 & $\begin{array}{l}\text { Sangat } \\
\text { tinggi }\end{array}$ & 82 & Rendah & 81 \\
\hline 11 & FMN & 176 & $\begin{array}{l}\text { Sangat } \\
\text { tinggi }\end{array}$ & 68 & $\begin{array}{l}\text { Sangat } \\
\text { rendah }\end{array}$ & 108 \\
\hline 12 & FAW & 128 & Tinggi & 78 & $\begin{array}{l}\text { Sangat } \\
\text { rendah }\end{array}$ & 50 \\
\hline 13 & GAS & 149 & $\begin{array}{l}\text { Sangat } \\
\text { tinggi }\end{array}$ & 78 & $\begin{array}{l}\text { Sangat } \\
\text { rendah }\end{array}$ & 71 \\
\hline 14 & $\mathrm{HMF}$ & 143 & $\begin{array}{l}\text { Sangat } \\
\text { tinggi }\end{array}$ & 63 & $\begin{array}{l}\text { Sangat } \\
\text { rendah }\end{array}$ & 80 \\
\hline 15 & IC & 158 & $\begin{array}{l}\text { Sangat } \\
\text { tinggi }\end{array}$ & 67 & $\begin{array}{l}\text { Sangat } \\
\text { rendah }\end{array}$ & 91 \\
\hline 16 & $\mathrm{JF}$ & 136 & Tinggi & 79 & Rendah & 57 \\
\hline 17 & MPS & 172 & $\begin{array}{l}\text { Sangat } \\
\text { tinggi }\end{array}$ & 87 & Rendah & 85 \\
\hline 18 & MIF & 145 & $\begin{array}{l}\text { Sangat } \\
\text { tinggi }\end{array}$ & 66 & $\begin{array}{l}\text { Sangat } \\
\text { rendah }\end{array}$ & 79 \\
\hline 19 & MDP & 170 & $\begin{array}{l}\text { Sangat } \\
\text { tinggi }\end{array}$ & 72 & $\begin{array}{l}\text { Sangat } \\
\text { rendah }\end{array}$ & 98 \\
\hline 20 & MHZ & 167 & $\begin{array}{l}\text { Sangat } \\
\text { tinggi }\end{array}$ & 91 & Rendah & 76 \\
\hline 21 & MRR & 178 & $\begin{array}{l}\text { Sangat } \\
\text { tinggi }\end{array}$ & 84 & Rendah & 94 \\
\hline 22 & NS & 166 & $\begin{array}{c}\text { Sangat } \\
\text { tinggi }\end{array}$ & 68 & $\begin{array}{l}\text { Sangat } \\
\text { rendah }\end{array}$ & 98 \\
\hline 23 & $\mathrm{NNF}$ & 126 & Tinggi & 61 & $\begin{array}{l}\text { Sangat } \\
\text { rendah }\end{array}$ & 65 \\
\hline 24 & RRP & 161 & $\begin{array}{l}\text { Sangat } \\
\text { tinggi }\end{array}$ & 66 & $\begin{array}{l}\text { Sangat } \\
\text { rendah }\end{array}$ & 95 \\
\hline 25 & RA & 161 & $\begin{array}{c}\text { Sangat } \\
\text { tinggi }\end{array}$ & 79 & Rendah & 82 \\
\hline 26 & $\mathrm{RN}$ & 110 & Sedang & 71 & $\begin{array}{l}\text { Sangat } \\
\text { rendah }\end{array}$ & 39 \\
\hline 27 & RG & 168 & $\begin{array}{l}\text { Sangat } \\
\text { tinggi }\end{array}$ & 87 & Rendah & 81 \\
\hline 28 & SAK & 167 & $\begin{array}{l}\text { Sangat } \\
\text { tinggi }\end{array}$ & 97 & Sedang & 70 \\
\hline 29 & SRD & 166 & $\begin{array}{l}\text { Sangat } \\
\text { tinggi }\end{array}$ & 87 & Rendah & 79 \\
\hline 30 & SA & 154 & $\begin{array}{l}\text { Sangat } \\
\text { tinggi }\end{array}$ & 95 & Sedang & 59 \\
\hline 31 & SM & 120 & Tinggi & 97 & Sedang & 23 \\
\hline 32 & TW & 132 & Tinggi & 79 & Rendah & 53 \\
\hline 33 & $\mathrm{ZM}$ & 99 & Sedang & 82 & Rendah & 17 \\
\hline
\end{tabular}




\begin{tabular}{ccccccc}
\hline 34 & MA & 161 & $\begin{array}{c}\text { Sangat } \\
\text { tinggi }\end{array}$ & 91 & Rendah & 70 \\
\hline Total & 5.085 & & 2757 & & 2328 \\
\hline Rata-rata & 149,5 & $\begin{array}{l}\text { Sangat } \\
\text { tinggi }\end{array}$ & 81,08 & Rendah & 68,47 \\
\hline
\end{tabular}

Dari data Tabel 5 Penurunan skor, yang mengalami penurunan kecemasan berbicara siswa di depan kelas, terdapat siswa yang awalnya dilaksanakan pre-test mengalami tingkat kecemasan berbicara di depan kelas dengan kategori sangat tinggi, tinggi, dan sedang. Setelah diberikan treatment layanan penguasan konten dengan teknik modeling, adanya perubahan penurunan kecemasan berbicara siswa di depan kelas ini dapat di lihat dengan dilaksanakan post-test. Perbandingan skor sebelum (pre-test) dan setelah (post-test) serta diberikan layanan penguasaan konten dengan teknik modeling dapat dilihat pada Tabel 4.8 Penurunan skor.

Pengujian hipotesis dilakukan untuk mengetahui apakah ada pengaruh yang signifikan antara layanan penguasaan konten dengan teknik modeling untuk mengurangi kecemasan berbicara siswa di depan kelas VIII A di SMP N 13 Kota Bengkulu. Untuk menguji hipotesis tersebut peneliti menggunakan uji t dengan menggunakan software Statitiscal Packages for Social Science (SPSS).

Kriteria penerimaan atau penolakan hipotesis adalah jika nilai Sig. (2-tailed) $<0,05$ maka Ho ditolak, namun jika nilai Sig. (2-tailed) >0,05 maka Ho diterima. Berdasarkan hasil uji t sebesar 17.053 yang artinya ada perbedaan yang signifikan penurunan kecemasan berbicara siswa di depan kelas sebelum dan sesudah diberikan layanan. Berarti ada pengaruh layanan penguasaan konten dengan teknik modeling untuk mengurangi kecemasan berbicara siswa di depan kelas. Dapat dilihat pada nilai sig. (2-tailed) sebesar 0,000 yang artinya nilai sig. (2tailed) lebih kecil dari 0,005 maka hipotesis (Ho) ditolak dan (Ha) diterima. Dapat disimpulkan bahwa ada penurunan kecemasana berbicara siswa di depan kelas VIII A SMP N 13 Kota Bengkulu melalui layanan penguasaan konten dengan teknik modeling.

Kecemasan berbicara siswa di depan kelas di SMP N 13 Kota Bengkulu sebelum diberikan layanan penguasaan konten dengan teknik modelingdiketahui sebanyak 24 orang yang mengalami kecemasan berbicara di depan kelas dengan 
kategori sangat tinggi kriteria skor > 142, dengan kategori tinggi ketentuan skor 111 - 141 sebanyak 7 orang, kategori sedang ketentuan skor 95 - 110 sebanyak 3 orang. Sedangkan dengan kategori rendah dan sangat rendah tidak ada yang mengalami. Hal ini menunjukkan bahwa masih banyak siswa yang mengalami kecemasan berbicara di depan kelas hal ini telang didukung oleh hasil kegiatan teknik pengumpulan data melalui instrumen angket kecemasan berbicara sewaktu dilakukan pre-test.Kecemasan berbicara siswa di depan kelas di SMP N 13 Kota Bengkulu setelah diberikan layanan penguasaan konten dengan teknik modeling terjadi penurunan skor kecemasan berbicara siswa di depan kelas dengan hasil dilakukannya post-test. Sebanyak 3 orang yang megalami penurunan skor dengan kategori sedang dengan ketentuan skor 95 - 110, dengan kategori rendah ada sebayak 20 orang yang mengalami penurunan skor dengan ketentuan skor 79 94, kemudian dengan kategori sangat rendah ada sebanyak 11 orang yang mengalami penurunan skor dengan ketentuan skor $\leq 78$. Bisa dilihat dari hasil post-test bahwa ada penuruan skor dari kecemasan berbicara siswa di depan kelas. Bahwa tidak ada lagi siswa yang mengalami kecemasan berbicara di depan kelas dengan kategori skor sangat tinggi dan tinggi, setelah diberikan treatment layanan penguasaan konten dengan teknik modeling.

Namun dapat dilihat pada tabel penurunan skor, ada9 siswa yang mengalami penurunan skor sangat jauh dari kriteria sangat tinggi turun hingga ke keriteria sangat rendah bisa dilihat di tabel penurunan skor. Hal ini terjadi sewaktu pemberian layanan penguasaan konten dengan teknik modeling. Siswa dengan inisial FMN, GAS, HMF, IC, MIF, MDP, NS, NNF, RRP. Berdasarkan pengamatan siswa ini sangat antusias dalam mengikuti kegiatan, serta tingkat pemahaman berkaitan materi mereka sangat tinggi, serta mereka aktif dalam mengikuti kegiatan praktik mandiri berpidato di depan kelas. Serta video modeling juga memberikan motivasi untuk mereka dalam mengatasi kecemasan berbicara di depan kelas.

Penurunan skor yang signifikan jauh juga terjadi pada kriteria sangat tinggi turun hingga ke rendah, serta kriteria tingggi turun hingga ke sangat rendah. Siswa yang mengalami penurunan sangat signifikan jauh ini berjumlah 15 siswa. 
Dengan inisial AGR, ANO, AIK, AR, DML, ES, EN, FAW, MPS, MHZ, MRR, RA, RG, SRD, MA. Melalui pengamatan yang telah peneliti laksanakan pada pemberian layanan penguasaan konten dengan teknik modeling. Siswa ini sangat antusias dalam mengikuti kegiatan, serta tingkat pemahaman berkaitan materi mereka sangat tinggi, serta mereka aktif dalam mengikuti kegiatan praktik mandiri berpidato di depan kelas. Serta video modeling juga memberikan motivasi untuk mereka dalam mengatasi kecemasan berbicara di depan kelas.

Penurunan skor yang dikategorikan turun sangat jauh ini adalah karena siswa itu sendiri sangat antusias serta aktif dalam mengikuti setiap tahapan kegiatan. Hal ini berdasarkan pengamatan langsung ketika pemberian layanan penguasaan konten dengan teknik modelingyang dilaksanakan oleh peneliti. Serta materi-materi dan teknik modeling yang diberikan peneliti adalah materi yang sangat baik untuk siswa dalam mengatasi kecemasan berbicara di depan kelas. Namun ada juga beberapa siswa yang mengalami penurunan skor tidak terlalu jauh di ambang angka normal, hal ini tejadi karena beberapa siswa tersebut memang tingkat kecemasan berbicara di depan kelas tidak terlalu tinggi.

Dengan begini sudah terlihat bahwa semua siswa terpacu dan sangat antusias berani serta percaya diri untuk tampil berbicara di depan kelas setelah dilakukannya treatment layanan penguasaan konten dengan teknik modeling untuk mengurangi kecemasan berbicara siswa di depan kelas. Menurut Prayitno (dalam Rizki, Umu A 2017: 54), layanan penguasan konten merupakan layanan bantuan yang diberikan kepada peserta didik (individu maupun kelompok) agar peserta didik menguasai kemampuan ataupun kompetensi tertentu melalui kegiatan belajar. Tujuan utama layanan penguasaan konten ialah dikuasainya suatu konten tertentu, penguasaan ini perlu bagi siswa untuk menambah wawasan dan pemahaman, mengarahkan penilaian dan sikap, menguasai cara-cara atau kebiasaan tertentu, untuk memenuhi kebutuhannya dan mengatasi masalahmasalahnya.

Serta teknik modeling, menurut Bandura (dalam komalasari, dkk 2011: 176), modeling berakar dari teori Albert Bandura dengan teori belajar sosial. Penggunaan tehnik modeling (penokohan) telah dimulai pada akhir tahun 50-an, 
meliputi tokoh nyata, tokoh melalui film, tokoh imajinasi (imajiner). Beberapa istilah yang digunakan adalah penokohan (modeling), peniruan (imitation), dan belajar melalui pengamatan (observational learning). Penokohan istilah yang menunjukkan terjadinya proses belajar melalui pengamatan (observational learning) terhadap orang lain dan perubahan terjadi melalui peniruan. Peniruan (imitation) menunjukkan bahwa perilaku orang lain yang diamati, yang ditiru, lebih merupakan peniruan terhadap apa yang dilihat dan diamati. Proses belajar melalui pengamatan menunjukkan terjadinya proses belajar setelah mengamati perilaku pada orang lain.

Sedangkan kecemasan berbicara Menurut Rahmawati dan Nuroyo (2014: 676), kecemasan berbicara di depan umum sering di alami oleh siswa. Permasalahan ini terjadi karena ketidakmampuan individu ketika berhadapan dengan orang lain didepan umum.

Jadi dari uraiaan di atas dapat peneliti tarik kesimpulan bahwa layanan penguasaan konten dengan teknik modeling ini sangat cocok bagi siswa yang mengalami kecemasan berbicara. Selain siswa juga dapat mengoptimalkan agar menguasai suatu konten tertentu juga dapat menanggulanginya dengan proses penokohan (modeling), peniruan (imitation), dan belajar melalui pengamatan (observational learning) yang berguna untuk siswa-siswi menjadi bahan sebagai pembelajaran untuk mengurangi kecemasan saat berbicara di depan kelas maupun dimuka umum.

Teknik modeling ini adalah suatu komponen dari suatu strategi dimana peneliti menyediakan demonstrasi tentang tingkah laku yang menjadi tujuan pengamatan secara langsung. Model dapat berupa model sesungguhnya (live model) dan (symbolic modeling). Live model (contoh hidup) sangat cocok untuk megatasi siswa yang mengalami kecemasan berbicara di depan kelas karena dengan teknik ini siswa diharapakan mampu mengatasi kecemasan berbicara dengan melihat secara langsung contoh hidup yakni teman sebaya, guru, maupun konselor secara langsung, dan dibantu oleh modeling symbolic sebagai media yakni penayangan audio visual berupa tanyangan video, diharapakan kepada 
siswa-siswi yang mengalami kecemasan berbicara dapat terentaskan serta menambah kemampuan untuk mengembangkan dirinya sendiri.

Pada penelitian ini, Penelitian ini hanya terbatas pada materi yang terkait tentang kecemasan berbicara saja dan tidak membahas materi lain.Metode yang digunakan dalam hal pemberian layanan penguasaan konten metode ceramah, diskusi dan teknik modeling.Penelitian ini hanya berlaku pada siswa kelas VIII A saja sebagai sampel penelitian. Keterbatasan mendapatkan waktu dan kesempatan dalam memberikan layanan sangat singkat yang diberikan oleh pihak sekolah. Keterbatasan alat perlengkapan penelitian seperti infokus atau LCD yang peneliti tidak dapat pinjaman oleh pihak sekolah maupun Prodi Bimbingan dan Konseling Universitas Bengkulu.

\section{Kesimpulan}

Kecemasan berbicara siswa di depan kelas VIII A sebelum diberikan layanan penguasaan konten dengan teknik modeling masih tergolong sangat tinggi, dilihat dari hasil pre-test siswa sebelum diberikan treatment layanan penguasaan konten dengan teknik modeling.

Kecemasan berbicara siswa di depan kelas VIII A setelah diberikan layanan penguasaan konten dengan teknik modeling mengalami penurunan. Hal ini ditunjukkan dengan adanya penurunan skor yakni, penurunan kecemasan berbicara siswa di depan kelas setelah diberikan layanan penguasaan konten dengan teknik modeling yang dapat dilihat dari hasil post-test siswa setelah diberikan layanan.

Pengaruh layanan penguasaan konten dengan teknik modeling untuk mengurangi kecemasan berbicara siswa di depan kelas VIII A menunjukkan perubahan signifikan adanya penurunan kecemasan berbicara siswa di depan kelas. Dapat dilihat dari hasil skor post-test siswa yang menurun, serta pemahaman materi yang diberikan setiap pertemuan selalu meningkat dan siswa sudah berani tampil berbicara di depan kelas. Dapat disimpulkan terdapat pengaruh layanan penguasaan konten dengan teknik modeling untuk mengurangi kecemasan berbicara siswa di depan kelas. 


\section{Daftar Pustaka}

Amalia, U.R. (2017). Pengaruh Layanan Penguasaan Konten Teknik Mind Mapping Terhadap Motivasi Belajar Siswa.Indonesian Journal of Guidance and Counseling. Vol.6 No. 3. Universitas Negeri Semarang.

Cangara, H. (2011). Pengantar Ilmu Komunikasi. Jakarta: Rajagrafindo Persada.

Damayanti, R., \& Aeni, T. (2016) . Efektivitas Konseling Behavioral dengan Teknik Modeling untuk Mengatasi Perilaku Agresif pada peserta didik kelas VIII B SMP Negeri 07 Bandar Lampung.Jurnal IAIN Raden Intan Vol. 03 No. 1. IAIN Raden Intan Lampung.

Emzir. (2015). Metodologi Penelitian Pendidikan. Jakarta: Raja Grafindo Persada.

Komalasari. G. (2011). Teori dan Teknik Konseling. Jakarta. Indeks.

Prakoso B. P. (2015). Berfikir Positif Untuk Mengatasi Kecemasan Berbicara Di Depan Kelas.JurnalPsikologi UMS. Vol. 3. No. 3. Universitas Muhammadyah Surakarta.

Prayitno. 2004.Layanan L.1-L.9. Fakultas Ilmu Pendidikan : Penerbit Universitas Negeri Padang.

Rahmawati. N. (2014). Penerapan Terapi NLP (Neuro Linguistik Programming) Untuk Menurunkan Kecemasan Berbicara di Depan Umum Pada Sisiwa Kelas XI SMAN 2 Pare.Jurnal BK UNESA. Vol.04, No 03. Universitas Negeri Surabaya.

Sugiyono. (2009). Statistik untuk Penelitian. Bandung : Penerbit Alfabeta. 